Research, part of a Special Feature on Balancing Ecology and Community using Cumulative Effects Models

\title{
Scenario Analysis to Identify Viable Conservation Strategies in Paraguay's Imperiled Atlantic Forest
}

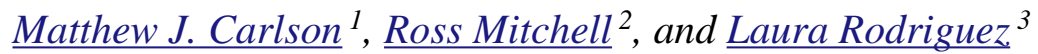

\begin{abstract}
A common challenge facing land use planning is assessment of the future performance of land use options. The challenge can be acute in developing regions where land use is expanding rapidly and funding and data needed for planning are scarce. To inform land use planning for a biosphere reserve located in Paraguay's Atlantic forest region, a scenario analysis explored the relative merits of conventional and conservation agricultural practices, sustained yield forestry, and protection. Simulations compared the long-term impacts on land cover, biotic carbon, and income of the area's residents. Ecological and economic decline were projected under conventional practices. Protection and forestry scenarios achieved only small relative improvements to ecological indicators at the cost of reduced economic performance. By addressing the underlying issue of land degradation, conservation agriculture including no-tillage was the most successful land use strategy both ecologically and economically. Identification of conservation agriculture as the most promising land use strategy prioritizes issues that must be addressed to achieve sustainability, most importantly the provision of education and funding to smallholder farmers. We conclude that scenario analysis offers a flexible strategy to integrate available data for the purpose of informing land use planning in data-limited regions such as Paraguay's Atlantic forest.
\end{abstract}

Key Words: Atlantic forest; conservation agriculture; deforestation; land use planning; Paraguay; scenario analysis; simulation

\section{INTRODUCTION}

Tropical deforestation is widespread with serious implications for biodiversity and ecosystem services, such as carbon storage. The extinction rate in the tropics could reach tens of thousands of species per decade this century (Pimm and Raven 2000), and tropical deforestation accounts for almost $20 \%$ of human-caused greenhouse gas emissions (Gullison et al. 2007). Reducing the rate of deforestation is made challenging by high poverty, with approximately 1 of every 12 people on the planet surviving by clearing forest to plant subsistence crops (Roper and Roberts 1999). It is essential that limited conservation resources be directed at strategies capable of stemming the loss of natural ecosystems while also addressing underlying socioeconomic issues.

Evaluating the future consequences of land use policy is constrained by uncertainty. Understanding of complex ecosystems and their response to human actions is incomplete, and knowledge gaps are likely to be larger in developing countries where institutional and technical capacity for their study is limited. Biodiversity monitoring and research are lower in the tropics relative to wealthier northern countries, despite higher levels of biodiversity (Collen et al. 2008). Although expanded ecological research in developing countries is necessary, the urgency to resolve environmental and socioeconomic problems is such that the development of sustainable land use policies cannot wait for findings from long-term research efforts. Agencies must make the best use of existing information to identify land use strategies suited to balancing ecological and economic objectives.

Scenario analysis (Peterson et al. 2003) is well suited for informing decision making when uncertainty surrounds future land use and its effects. In the context of land use planning, scenario analysis

${ }^{1}$ ALCES Group, ${ }^{2}$ Environmental Resources Management, ${ }^{3}$ Fundacíon Moisés Bertoni 
Fig. 1. The location of the Mbaracayu Forest Biosphere Reserve and Natural Reserve.

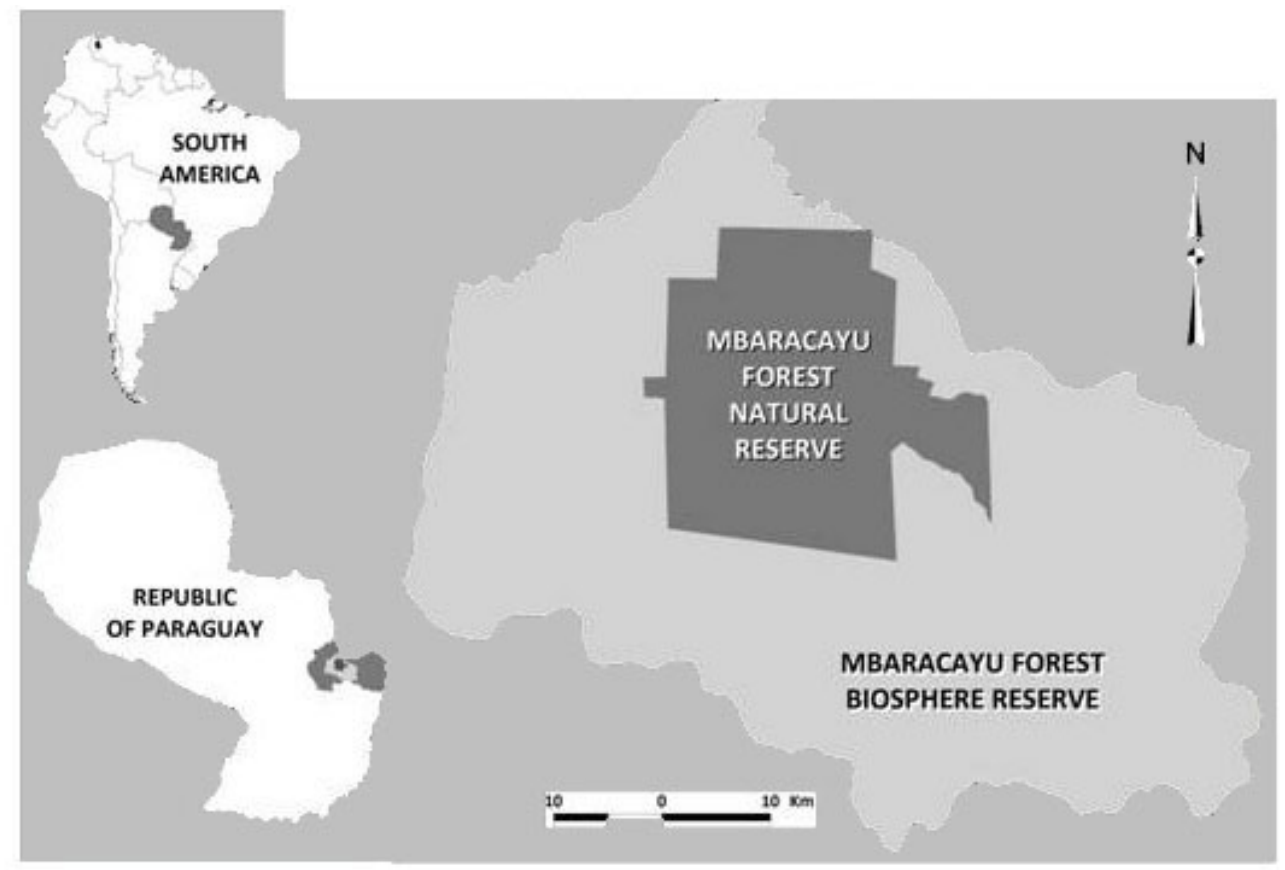

refers to integrating available technical information to explore the future implications of land use options to ecological and socioeconomic objectives (van Ittersum et al. 1998, Lu et al. 2003). The goal is not to develop an accurate prediction of the future, but rather to compare a range of possible scenarios with the intent of illuminating key drivers that should be the focus of land use policies.

The Upper Parana Atlantic forest of Paraguay provides a vivid example of the challenges faced when developing land use policy in the face of poverty, ecological degradation, and limited information for planning (Di Bitetti et al. 2003). The Atlantic forest region covers parts of Paraguay, Brazil, and Argentina and is considered a biodiversity hotspot due to high degrees of both species endemism and threat (Myers et al. 2000). Forest cover in Paraguay's Atlantic forest ecoregion decreased from $73 \%$ in 1973 to $25 \%$ in 2000 (Huang et al. 2007), a change of almost $50 \%$ in less than 30 years. At $-0.9 \%$ per year, Paraguay had the second highest rate of deforestation in South America between 2000 and 2005 (FAO 2006). In 2009, onefifth of the country's population remained below the poverty line (United Nations 2009). Despite the high rate of deforestation and negative implications for biodiversity and ecosystem services, ecological issues receive limited attention from both the government and the public in Paraguay (GalindoLeal and de Gusmao Camara 2003); this is further complicated by limited capacity for conservation research and planning (Catterson and Fragano 2004).

In 1991, responding to the rapid loss of Atlantic forest, the Government of Paraguay created the Mbaracayú Forest Natural Reserve (MFNR), located in the Canindeyú Department of northeastern Paraguay (Fig. 1). The watershed surrounding the reserve (Cuenca Alta del Rio Jejui, hereafter referred to as the Cuenca) was established as a Biosphere Reserve, a region containing both protected areas and sustainable development zones to support conservation and development functions. Between 1973 and 2004, forest cover in the Cuenca decreased from $90 \%$ to $56 \%$ as a result of conversion for cattle ranching, smallholder agriculture, and soybean production (Naidoo and Adamowicz 2006). The MFNR is the largest protected area in 
Table 1. Land use scenarios simulated in the study.

\begin{tabular}{llll}
\hline \hline Scenario name & Protection strategy & Agricultural practices & Forestry \\
\hline Conventional & Existing reserves & Conventional & Salvage only \\
Protection law & Existing reserves \& 25\% of forested property & Conventional & Salvage only \\
Conservation agriculture & Existing reserves & Conservation & Salvage only \\
Forestry & Existing reserves & Conventional & Sustained yield \\
\hline
\end{tabular}

Paraguay containing Atlantic forest (Di Bitetti et al. 2003), and the 291,962-hectare (ha) Cuenca is a Man and the Biosphere (MAB) UNESCO World Heritage Site in recognition of the potential to achieve a balanced relationship between people and nature in the region. MAB reserves are established to cultivate and demonstrate strategies for reconciling environmental protection with social and economic development. The Fundacíon Moisés Bertoni (FMB), a conservation nongovernmental organization in Paraguay, manages the MFNR and has established a program to integrate regional sustainable development and management of the protected area.

We present a scenario analysis that integrates available ecological and socioeconomic information to assess the future consequences of land use options in the Cuenca. The purpose of the analysis was to contribute to the FMB's land use planning efforts in the Cuenca and to inform dialogue with stakeholders. The study provides an example of the utility of scenario analysis as a land use planning tool, despite information constraints.

\section{METHODS}

The scenario analysis explored the long-term (50 year) ecological and economic consequences of four land use scenarios (Table 1). The scenarios represent a range of strategies for the three primary land uses in the Cuenca, namely agriculture, forest protection, and timber harvest. To achieve a small set of informative indicators, we assessed indicators prioritized by FMB staff at a workshop held in November 2005. Income generation was identified as the highest priority economic indicator, and we evaluated economic performance of the scenarios based on per capita net income from agriculture and forestry. Ecological indicators prioritized by FMB primarily related to changes in landscape composition, which we assessed by tracking simulated changes in natural land cover. We also simulated the effect of land use scenarios to biotic carbon due to its past and potential future role in financing conservation in the region. MFNR was one of the world's first carbon offset projects, with an energy company partially funding the establishment of the park through the purchase of carbon offsets (Zwick 2008).

We evaluated the potential future effects of land use scenarios using the ALCES land use simulation model (http://www.alces.ca). ALCES integrates the impacts of a wide range of land uses and ecological processes to assess potential cumulative effects to landscape composition, wildlife, ecosystem services, and the regional economy. Using an annual time-step, the model modifies landscape composition and tracks natural resource production and supply in response to land use and ecological processes. For the scenario analysis, ALCES converted natural land cover to farmland to offset declines in soil fertility and to achieve increases in production. Land cover was also affected by timber harvest in some simulations. Abandoned farmland, as well as harvested forest, gradually recovered through succession. ALCES then applied coefficients to estimate the response of carbon storage to simulated changes in landscape composition and the response of net income to changes in resource production (Fig. 2). A companion mapping tool (ALCES Mapper) was not yet available when the scenario analysis was undertaken and, as a result, spatially explicit 
Fig. 2. Simulation model overview. The model tracks changes in landscape composition, soil fertility, and resource production in response to simulated land use trajectories. In turn, changes to landscape composition and fertility as well as succession affect future land use patterns. Simulated changes to landscape composition and resource production are used to calculate second-order impacts, including biotic carbon storage and net income generation.

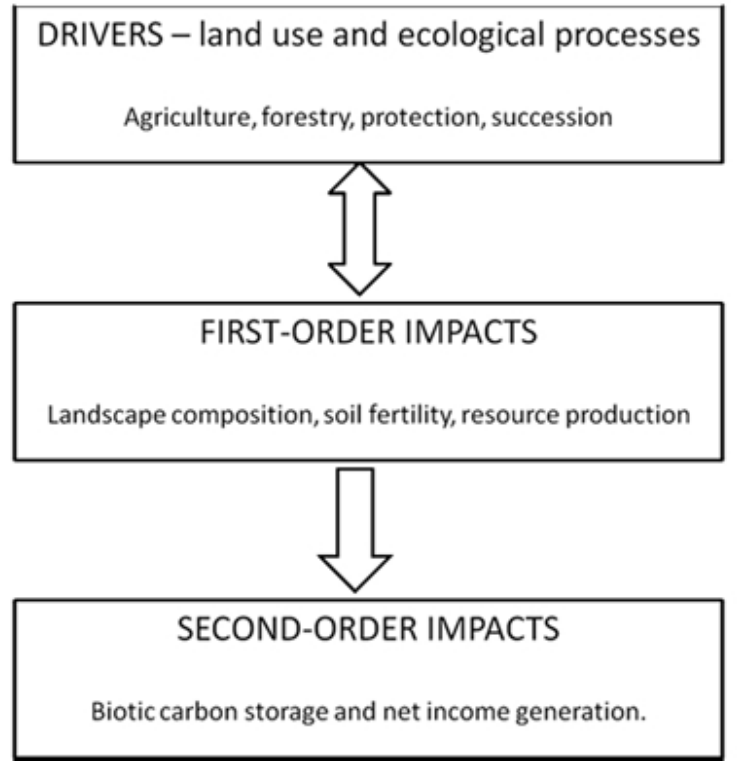

indicators such as habitat fragmentation were not assessed. ALCES is extensively used in western North America to inform land use planning in both agriculture and forest-dominated regions (e.g., Alberta Environment 2007) and assess the cumulative effects of resource development (e.g., Schneider et al. 2003, Carlson et al. 2009). Only minor modifications to the model were required prior to application to the Cuenca due to a user interface that allows specification of a wide range of landscape types, land uses, and ecological processes.

\section{Simulation assumptions}

As described below, a variety of sources were used to parameterize ALCES for the Cuenca based on a thorough review of data held by the MFNR manager and a search of primary and gray (secondary) literature. Several assumptions were based on historical trends, especially for future rates of development. Although future land use will not necessarily follow past patterns, extrapolation of historical trends helped inform the development of plausible land use scenarios.
During March 2006, a series of workshops were held with government ministries and nongovernmental organizations in Asuncion and with land holders and park managers in the Cuenca to ensure that the best available data were being appropriately used for the scenario analysis. Few participants had the technical background for understanding complex planning tools such as ALCES and related concepts such as indicators and coefficients. To address this challenge, workshops were undertaken to educate participants about the potential role of scenario analysis in land use planning. This approach was very successful according to participants and resulted in a more widespread comprehension and buy-in.

\section{Landscape composition}

The initial composition of the Cuenca was estimated using a land cover data set created by classifying a 2001 Landsat satellite image using traditional ecological knowledge for class interpretation (Naidoo and Hill 2006). Land use and land cover were summarized into 10 natural vegetation types and three agriculture types (smallholder cultivation, soybean plantation, and ranch). Smallholder farms 
were farms less than 20 ha in size producing a variety of subsistence (e.g., mandioca) and cash crops (e. g., cotton). Although a range of crops are grown by smallholder farms in the region, the simulations assumed a mix of cotton, maize, mandioca, and pasture that, together, accounted for $82 \%$ of the crop mix at farms studied by Florentin et al. (2001) in the nearby San Pedro district. The other two agriculture types were soybean plantations and ranches. Soybean plantations are large farms used for the industrial production of soybean, and ranches are large farms used to raise cattle. Based on the satellite data from 2001, 66\% (192,115 ha) of the Cuenca was natural vegetation, $17 \%(49,037$ ha) was ranchland, $15 \%(42,709$ ha) was smallholder farmland, and $3 \%(8,102$ ha) was soybean plantation.

\section{Agriculture}

Agricultural activity in the Cuenca has increased 10 -fold over the past 30 years. Our simulations assumed that agricultural activity will continue to expand. In the absence of information needed to parameterize potential interactions, future trends in agricultural activity were assumed to be independent across farm types. Smallholder production was assumed to reflect rural population growth and expanded in simulations at $1.5 \%$ per year, the average population growth rate in the region between 1990 and 2000 (UNDP 2003). Soybean production, on the other hand, was assumed to be driven by international demand and grew linearly each year by $6.1 \%$ of the current level of production; this growth pattern was based on projections by industry and government (Dros 2004). Extrapolated over the 50-year simulation period, these rates of growth imply an approximate doubling of productive smallholder farm area to nearly 90,000 ha and tripling of productive soybean plantation area to over 30,000 ha. In contrast, cattle production did not increase during the simulations because the cattle population was relatively stable in the region between 1992 and 2004 (Ministerio de Agricultura y Ganaderia 2004). In the simulations, the location of cropland expansion was based on an analysis of historical agricultural expansion in the Cuenca that assigned spatially explicit conversion probabilities to natural areas remaining in the region (Naidoo and Adamowicz 2006). The conversion probabilities were combined with land cover data to derive the relative probability of each natural cover type being converted to one of the three agricultural land uses considered for this analysis.
Simulations with ALCES also explored two types of agricultural practices: conventional and conservation. Conservation agriculture refers to a suite of practices intended to improve sustainability, including no-tillage (or zero tillage), direct seeding, crop rotations, green manure cover crops, and crop residue management (Lange 2005). Sorrenson et al. (1998) report that, of the $1,700,000$ ha of smallholder farms in Paraguay, only approximately 6500 ha $(0.4 \%)$ are farmed using conservation agriculture; in contrast, Lange (2005) reports that $60 \%$ of the total mechanized medium and large farms in Paraguay used no-tillage agriculture as of 2002. Implementation of no-tillage practices in the conventional scenario was assumed to be $0.4 \%$ and $60 \%$ for smallholder farms and soy plantations, respectively. The conservation agriculture scenario assumed rapid adoption of no-tillage practices (100\% of farms by year 10$)$ in order to estimate the upper bound of gains that might be achievable. Also included in the conservation agriculture scenario was the strategy proposed by Dros (2004) of expanding soy plantations through conversion of ranchland (instead of native vegetation) in order to reduce forest loss.

Farm productivity was based on multiyear studies of Paraguayan farms in nearby regions. For smallholder farms, simulated net income generation per hectare was based on 20-year conventional crop productivity trends (Florentin et al. 2001), which included gradual declines in maize and cotton productivity (but not cassava and livestock) after clearing due to diminishing soil fertility. Based on a 5-year comparison of conservation and conventional agriculture (Lange 2005), application of conservation agriculture in the simulations caused cotton, maize, and cassava productivity to increase relative to conventional agriculture and avoided declines in productivity over time. For soybean plantations, net income generation was based on 10-year trends under conventional and conservation agriculture at soybean farms in nearby districts (Sorrenson 1997). As with smallholder farms, conventional practices for soybean plantations caused productivity to decline over time, whereas conservation agriculture achieved higher and sustained productivity.

We assumed that cropland would be abandoned when productivity was no longer sufficient to cover farming costs, i.e., when net income was below zero. Based on extrapolation of long-term crop productivity trends in the region (Sorrenson 1997, 
Florentin et al. 2001), abandonment occurred 26 years after clearing for cotton, 12 years for maize, and 7 years for soybean. If farmers abandon cropland prior to net income declining to zero, simulated rates of farm abandonment will be conservative. After abandonment, cropland was assumed to require a 30 -year fallow period to restore soil fertility capable of once again supporting a native plant community or crop production.

Net income generation by ranchland was based on a stocking rate of 1.5 cattle/ha (Ministerio de Agricultura y Ganaderia 2004), an annual slaughter rate of $13 \%$ (FAO 2005), and recent prices for slaughtered cattle in Paraguay adjusted to account for the cost of transporting cattle to market. Unlike cropland, simulated net income generation by ranchland did not decline over time.

\section{Forestry}

When forest is cleared for agriculture in Paraguay, harvesting of trees is highly selective with only $3 \%$ of wood volume used for lumber and the remainder burned (Grauel 1996). As an alternative to converting forest to agriculture, we simulated a forestry scenario in which all unprotected merchantable forest is dedicated to sustained yield timber production. A forest inventory from a property in the Cuenca was used to estimate mature wood volume of 36.7 cubic meters $\left(\mathrm{m}^{3}\right) /$ ha based on a minimum harvestable diameter of 40 centimeters. Based on a study of reduced impact logging practices in eastern Amazonia (Holmes et al. 1999), we assumed a utilization rate of $46.55 \%$, resulting in a net timber productivity of $17 \mathrm{~m}^{3} / \mathrm{ha}$. Using approximate prices paid for standing timber in the region, the value of harvested timber was estimated at US $\$ 9.41 / \mathrm{m}^{3}$. A rotational cycle of 30 years was assumed (Vanclay 1994, Jackson et al. 2002, Carvalho et al. 2004). The total annual rate of harvest for the Cuenca was $9820 \mathrm{~m}^{3}$; this estimated sustained yield was based on the availability of merchantable timber and associated assumptions of productivity, utilization rate, and rotation age.

\section{Protection}

Twenty-eight percent of the Cuenca is protected, including the 64,268 ha MFNR, 14,067 ha in indigenous reserves, and 4453 ha in private reserves. The private reserves are protected from agriculture but available for logging. All other reserves were assumed to be protected from agriculture and forestry. The protection scenario evaluated the effects of full implementation of the rarely practiced Forest Law of 1973, which stipulates that at least $25 \%$ of any forested property in Paraguay must be maintained as a forest reserve (Glastra 1999). Implementation of the Forest Law increased protection from $28 \%$ to $38 \%$ of the Cuenca.

\section{Indicators}

Calculation of biotic carbon storage associated with simulated landscape composition was based on biomass estimates from tree plots sampled in the Cuenca (Naidoo and Ricketts 2006) and known allometric relationships (Brown et al. 1989). Carbon storage calculations were restricted to aboveground biomass due to uncertainty surrounding belowground biomass and soil carbon and their sensitivities to land use changes. Assumed aboveground carbon densities for native vegetation ranged from 25 to 106 tonnes/ha, depending on the land cover type. Conversion to agriculture eliminated all biotic carbon, whereas abandoned cropland accumulated carbon at a rate of 1.47 tonnes/ha/year (Zarin et al. 2001). Forestry activities reduced carbon storage capacity through timber removal and emissions from coarse woody debris created from tree damage during forestry activities. Assuming a wood density ratio of 0.6 tonnes $/ \mathrm{m}^{3}$ (Brown 1997), carbon exported as logs was 5.1 tonnes/ha. Carbon emissions from coarse woody debris were 2.4 times the carbon exported as logs (Feldpausch et al. 2005), resulting in an overall carbon loss of 17.3 tonnes/ ha. Preharvest aboveground biomass was assumed to regenerate over one harvest cycle (30 years).

Per capita net income was calculated by dividing simulated agriculture and forestry net income by the Cuenca's human population. Simulations assumed that the population increased at a rate of $1.5 \%$ per year from 30,000 at simulation year 0 to 62,224 by simulation year 50 . It should be noted that simulated per capita net income underestimates regional economic activity because it only accounts for income directly generated by agriculture and forestry. Other income may be generated from indirect or induced economic activities associated with agriculture and forestry or from other activities entirely, such as government services or illegal operations (e.g., marijuana plantations, wildlife poaching). 
Table 2. Indicator status at that start of the simulation and after 50 years under the four land use scenarios.

\begin{tabular}{lccc}
\hline \hline Scenario & $\begin{array}{c}\text { Natural land cover } \\
\text { (ha) }\end{array}$ & $\begin{array}{c}\text { Per capita net income } \\
\text { (US\$/year) }\end{array}$ & $\begin{array}{c}\text { Biotic carbon } \\
\text { (tonnes) }\end{array}$ \\
\hline Simulation year 0 & 192,115 & 509 & $9,010,194$ \\
Conventional agriculture year 50 & 86,174 & 385 & $6,678,939$ \\
Conservation agriculture year 50 & 149,715 & 625 & $7,585,443$ \\
Protection law year 50 & 115,284 & 364 & $7,449,551$ \\
Forestry year 50 & 109,373 & 361 & $7,694,797$ \\
\hline
\end{tabular}

\section{RESULTS}

Economic and ecological performance declined substantially by simulation year 50 under the conventional scenario relative to year 0 (Table 2). Natural land cover and carbon storage reduced by $55 \%$ and $26 \%$, respectively, whereas per capita net income declined by $24 \%$. Although the protection law and forestry scenarios were better able to conserve natural land cover and biotic carbon, they resulted in slightly lower per capita net income relative to the conventional scenario. The conservation agriculture scenario, however, conserved natural land cover and carbon while actually increasing per capita net income relative to simulation year 0 .

Natural land declined in simulations (Fig. 3), primarily to offset the loss of productive cropland from unsustainable agricultural practices. The decline in natural land continued until all available land (i.e., land not reserved for other uses) was converted to agriculture, which occurred by years 33,27 , and 25 in the conventional, forestry, and protection law scenarios, respectively. Exhaustion of available land occurred earlier in the protection and forestry scenarios than the conventional scenario because more land was protected from agricultural conversion, either for long-term timber production or as an ecological reserve. The conservation agriculture scenario did not require the conversion of all available natural land to agriculture due to two strategies: (1) conservation farming practices that eliminated the need to abandon cropland and (2) all soybean plantation expansion occurred into ranchland rather than natural land. The area of natural land conserved by these two strategies was approximately equivalent, with sustainable farming practices conserving 30,006 ha and ranchland conversion conserving 33,535 ha compared with the conventional scenario. Simulated response of carbon storage was similar to that of natural land cover. Biotic carbon was reduced during the simulation due to conversion of forest to cropland, until all available natural land was lost. Scenarios that reduced the rate of deforestation, most notably conservation agriculture, were better able to conserve biotic carbon (Fig. 4). Biotic carbon increased during the final decades of the simulation in scenarios with high cropland abandonment (i.e., conventional agriculture, protection law, forestry) due to gradual recovery of biotic carbon on abandoned cropland with secondary forest regrowth.

Per capita net income was relatively stable under the conventional scenario until halfway through the fourth decade, at which point it began to decline (Fig. 5). The cause of the decline was the exhaustion of all unprotected natural land cover, with the result that clearing of forest for agriculture was no longer possible to offset declines in crop productivity caused by unsustainable agricultural practices. Although abandoned cropland returned to production after a 30-year fallow period, the process was too gradual to compensate for declines in crop productivity. The decline in net income occurred earlier in the protection and forestry scenarios because less natural land was available for 
Fig. 3. Simulated change in natural land in the Cuenca under four land use scenarios.

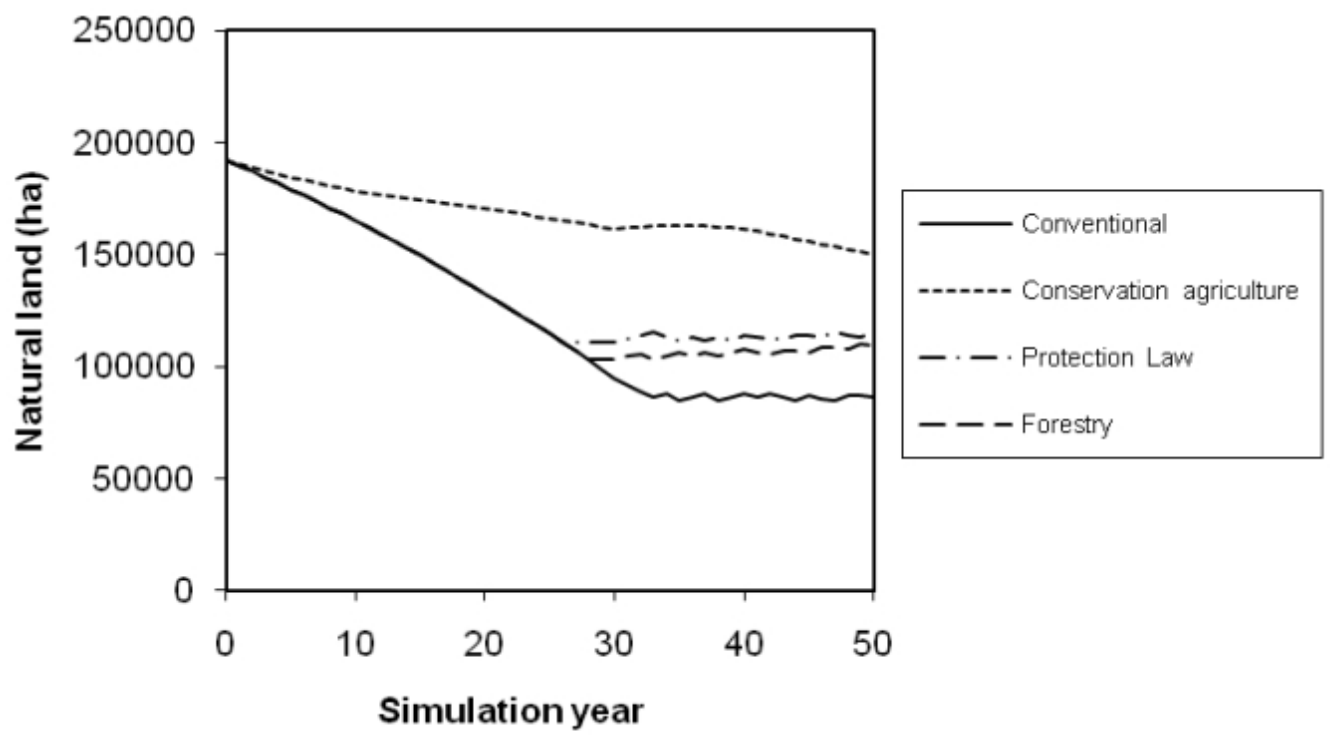

conversion to cropland. In the short term, conservation agriculture generated marginally lower net income relative to conventional agriculture because less land was dedicated to the production of economically valuable cotton, the predominant cash crop in the Cuenca. Over the long term, however, the conservation scenario achieved the greatest net income because declines in crop productivity from reduced soil fertility were avoided. Across all scenarios, net income was dominated by contributions from smallholder farms $(80 \%)$, followed by soy plantations (15\%). Ranching and forestry contributions to net income were minimal.

\section{DISCUSSION}

The scenario analysis suggests that the Cuenca will continue to experience poverty and ecological degradation if current practices continue, with increased severity of both over time. Unsustainable agriculture clearly emerges from the analysis as a primary driver of the system, causing an agricultural resource production shortfall and widespread deforestation over time with concomitant declines in carbon storage. This outcome is consistent with a review of tropical deforestation case studies that found agriculture to be the most prevalent direct cause (Geist and Lambin 2002).

Our simulations demonstrate that sustainable development in the form of conservation agriculture is best suited to FMB's programmatic efforts in support of both biodiversity and the wellbeing of local inhabitants. Wide-scale adoption of conservation practices such as no-tillage and crop residue management may not only maintain but actually increase the productivity of farmland within the region. As a result, abandonment of farmland would no longer be necessary, and pressure to convert natural land would decrease. Despite the economic and environmental benefits of conservation agriculture, implementation is challenging because it requires upfront investment in machinery and other inputs, such as green manure cover crop seeds (Lange 2005). Although productivity gains under conservation agriculture are immediate and can soon offset the investment, farmers may understandably perceive implementation of a new agricultural strategy as an economic risk. Financial support is needed to provide farmers with sufficient credit to implement conservation agriculture (Lange 2005), and few such mechanisms are currently available for smallholder farming. 
Fig. 4. Simulated aboveground biotic carbon storage in the Cuenca under four land use scenarios.

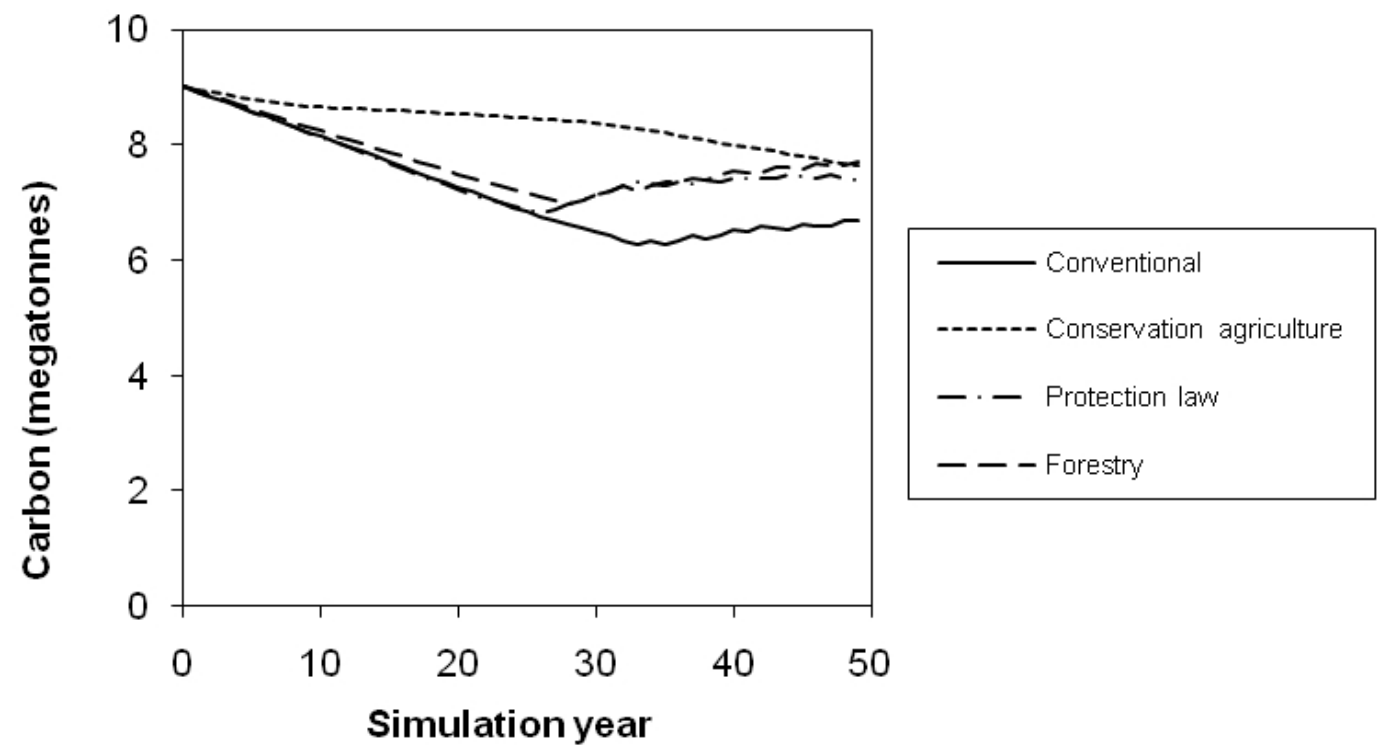

Also important are extension services to increase recognition of the benefits of conservation agriculture and improve capacity to adopt conservation practices (Pannell et al. 2006).

Simulation of the forest protection law demonstrated that protection can reduce deforestation but to the potential detriment of income generation if underlying land use issues are not addressed. The failure of protected areas to improve land use beyond park borders is consistent with an analysis of Landsat imagery that found deforestation within $5 \mathrm{~km}$ of forested protected areas to be the same as elsewhere within Paraguay's Atlantic forest ecoregion (Huang et al. 2007). Protected areas and sustainable development are not necessarily a dichotomy, and many forest conservation strategies recommend a combination of both (e.g., Pence et al. 2003). Successful enforcement of the forest protection law in conjunction with conservation agriculture in the Cuenca would achieve long-term economic productivity while also ensuring the longterm persistence of natural ecosystems. To ensure that new protected areas are effective, their location should be informed by the available spatial information, such as the costs and benefits of protection across the Cuenca (Naidoo and Rickets 2006) and a conservation plan for the broader ecoregion (Di Bitetti et al. 2003). Future scenario analysis efforts should consider the application of spatial tools, such as ALCES Mapper, to assess the long-term implications of protected area network designs and other zoning decisions. The aspatial nature of the scenario analysis does not, however, detract from the legitimacy of the key finding that large-scale deforestation can be expected in the absence of sustainable agriculture. Given that all unprotected forest was converted to agriculture during the conventional agriculture scenario, the spatial dynamics of the simulated deforestation are of limited importance.

We assume that pressure to expand agricultural production will be substantial due to population growth and international demand for soy. The scenarios attempted to double smallholder agricultural production and triple soybean production. Although these are substantial increases, they were achievable in the presence of conservation agriculture and are consistent with historical agricultural growth in the region. The simulated growth in converted land closely matched actual growth since 1973 (Fig. 6), suggesting that our assessment of future agricultural deforestation is reasonable. In fact, our simulations may underestimate deforestation due to conservative 
Fig. 5. Simulated net income per capita generated by agriculture and forestry in the Cuenca under four land use scenarios.

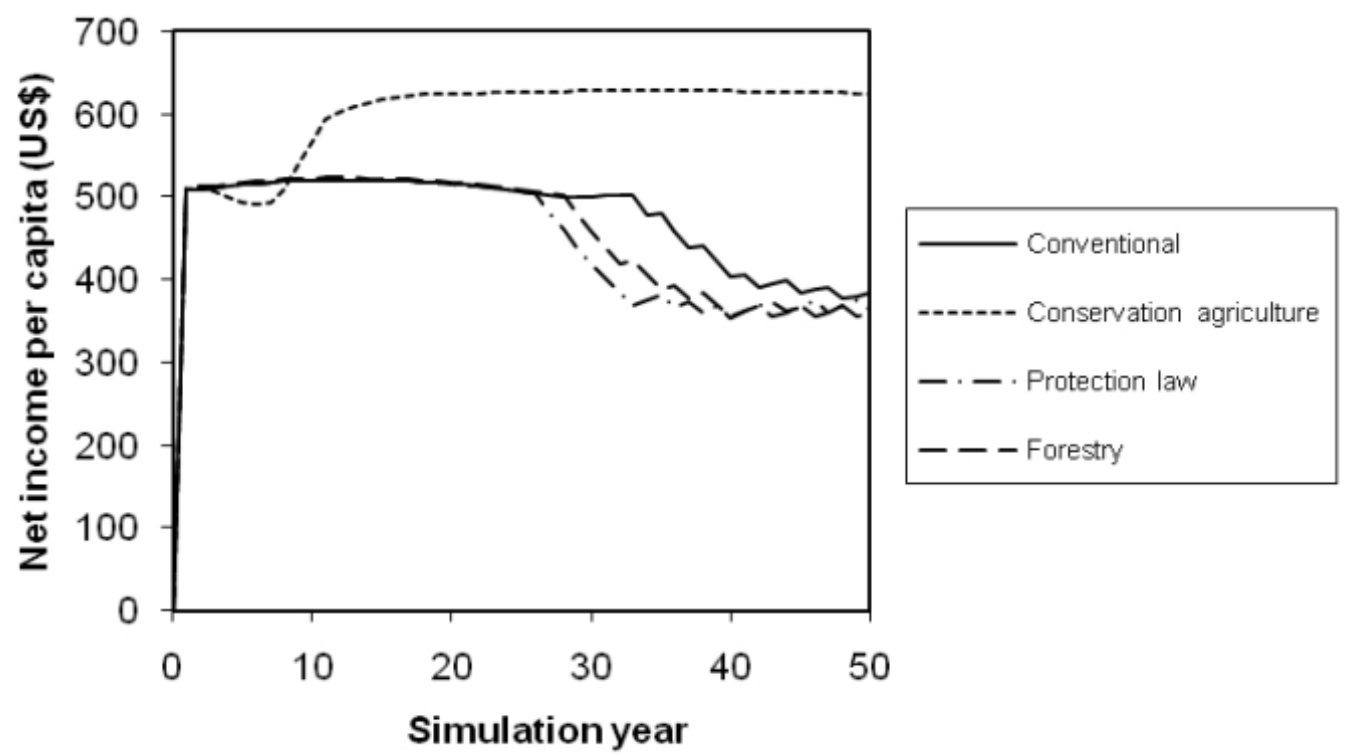

assumptions that were adopted to avoid exaggerating the rate of forest loss. Farmers may abandon land in favor of more fertile farmland prior to the threshold of zero net income that was assumed in simulations. The assumed 30-year fallow period after abandonment may also be optimistic given that 25 years of regrowth after slash-and-burn agriculture restored only half of mature-forest biomass in central Amazonia (Gehring et al. 2005) and that 11 years of fallow was required after each year of crop production in the northeastern Brazilian Amazon (Metzger 2002). Alternatively, the consequences of deforestation may be exaggerated if abandoned cropland has economic or ecological value. Abandoned cropland could be used for pasture, but this would not change the trend of diminishing economic performance because income generation is several times lower for livestock than crop production. With respect to ecological implications, abandoned farmland is likely to have reduced biodiversity value relative to primary forest well beyond 30 years (Gehring et al. 2005, Guerrero and da Rocha 2009, Tabarelli et al. 2010).

As these uncertainties highlight, the scenario analysis should not be considered a forecast but rather a set of plausible and relevant stories to demonstrate the relative implications of management strategies (Schneider et al. 2007). Accurate forecasting is problematic due to uncertainty (Peterson et al. 2003). Market forces, demographic patterns, climatic conditions, and other external drivers are almost certain to change in unexpected ways during the 50-year simulation period. Despite potential inaccuracies, however, the scenario analysis is illuminating because it draws attention to the key management issue (deforestation) and its underlying cause (unsustainable agriculture). Given the dominant influence of deforestation, we assessed the sensitivity of simulation outcomes to the following assumptions that governed the simulated deforestation rate: rate of decline in cropland productivity, regional growth in agricultural production, and the time required for recovery of abandoned cropland. A set of six simulations was conducted; in each simulation, a given assumption was increased or decreased by $25 \%$ while keeping the other parameters at the conventional scenario's settings. Although indicators such as net income per capita were influenced by changes to the assumptions (Fig. 7), the overall pattern was largely unaffected. Net income increased until all available land had been converted to agriculture and declined thereafter. As long as 
Fig. 6. Growth in agricultural land in the Cuenca according to historical data and the conventional scenario simulation.

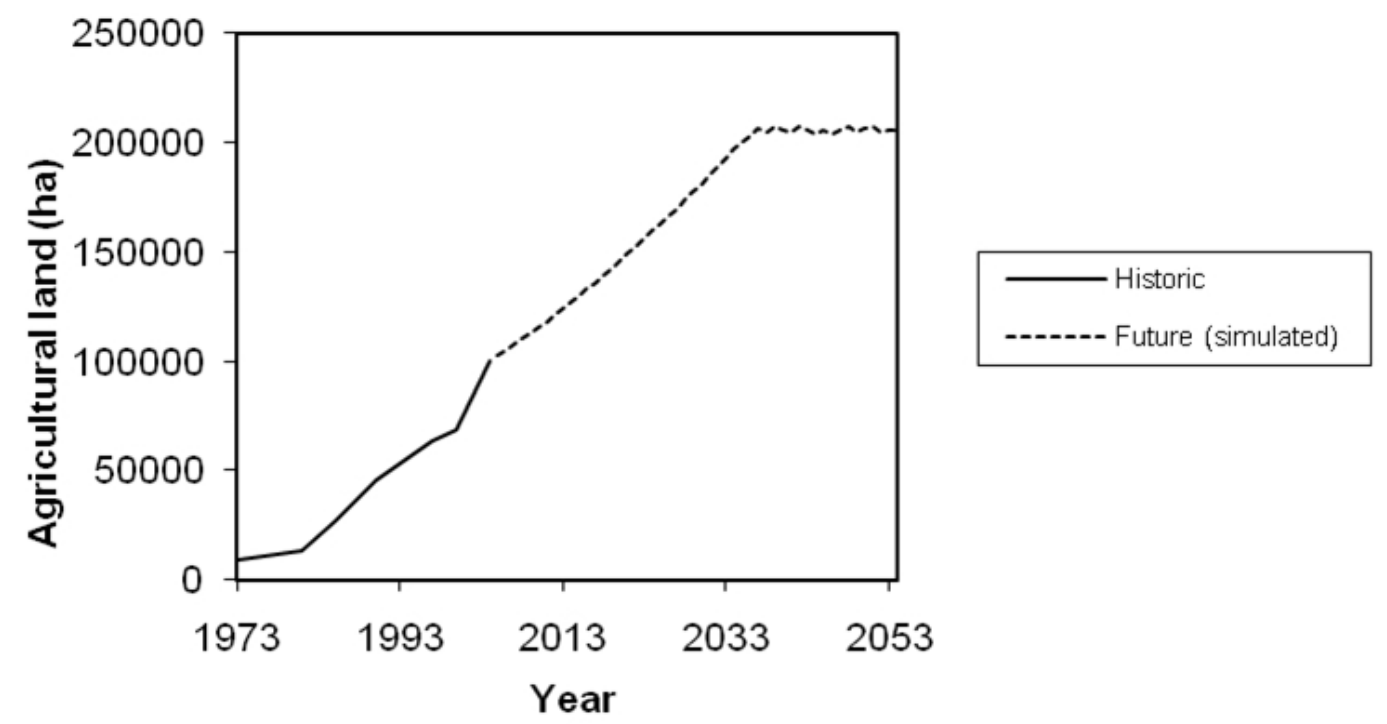

agricultural production in the Cuenca continues, which seems probable, conservation agriculture is likely a prerequisite for long-term sustainability.

The services provided by intact ecosystems are typically undervalued; as a result, the financing of conservation strategies, such as conservation agriculture and implementation of the protection law, can be problematic. Perhaps the greatest opportunity for the financing of tropical forest conservation is through the sale of carbon offsets. The simulations demonstrated the capacity of conservation agriculture to reduce the loss of biotic carbon associated with conventional agricultural practices. The simulations may, in fact, underestimate the carbon-related benefits of conservation agriculture because the role of notillage in increasing soil carbon storage (Amado et al. 2006) was not considered and because carbon storage was lower than has been assumed elsewhere for Atlantic forest (e.g., Ditt et al. 2010).

Although not assessed in the simulations, deforestation associated with conventional agriculture is also problematic for wildlife and water quality. The Cuenca's rich biodiversity, including numerous species important for indigenous subsistence hunting (Hill et al. 2003), would likely decline with deforestation. Cropland and small forest fragments support less biodiversity than large reserves (Chiarello 1999), and the impact of hunting associated with settlement and an expanding road network is likely greater than subsistence hunting (Putz et al. 2000). Water quality would also decline with deforestation due to sedimentation and contaminated agricultural runoff (Ditt et al. 2010). Contamination can also occur under conservation agriculture if herbicides are relied on to combat increased weeds associated with no-tillage. The application of herbicides along with soybean plantation expansion in eastern Paraguay over the past 30 years has been criticized by some authors (Fogel and Riquelme 2005, Semino et al. 2006). Notillage and water contamination need not be synonymous, however. Alternative strategies for weed control, such as crop rotation and maintaining permanent organic soil cover, can reduce reliance on herbicides (Landers 2007). Wildlife and water quality were not assessed in simulations because data were insufficient; additional research to assess these key uncertainties is needed.

Existing policies and practices suggest that the benefits of conservation agriculture are not fully appreciated. Conservation targets established by 
Fig. 7. Sensitivity of simulated net income per capita under the conventional scenario to changes in net income rate, abandoned cropland reclamation rate, and agriculture production growth rate assumptions.

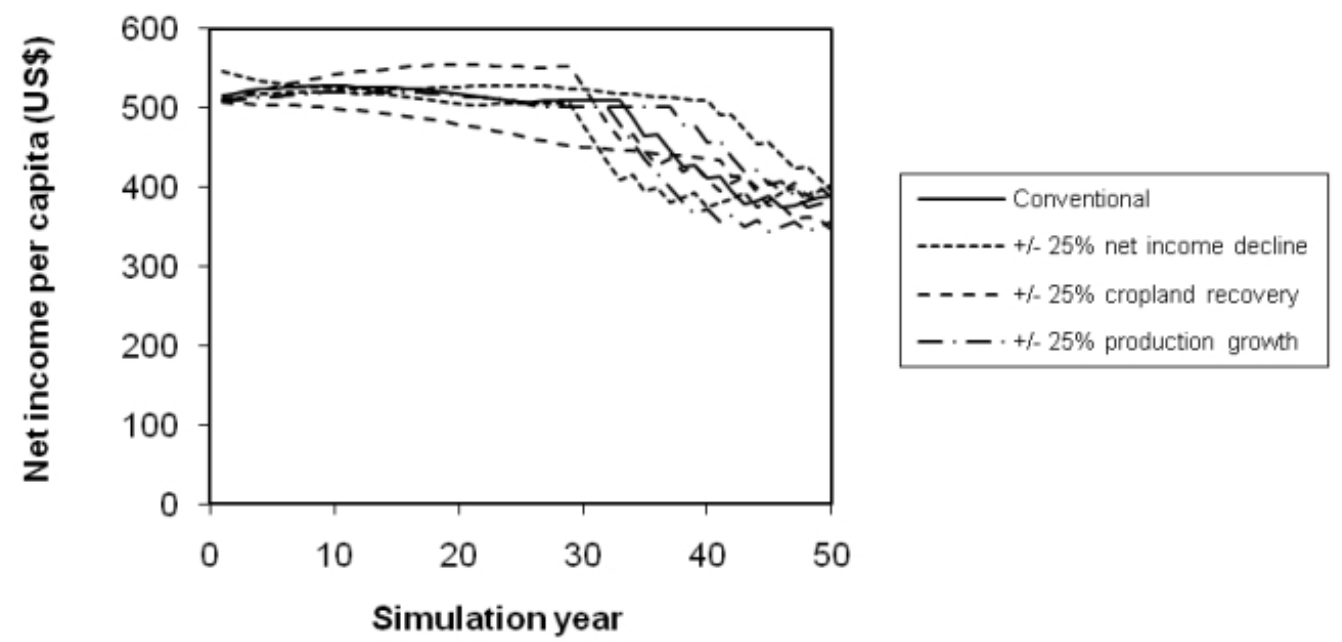

nongovernment organizations for the region focus on establishing conservation zones and restoring forest, with minimal reference to strategies for addressing unsustainable agricultural practices that are driving deforestation (Di Bitetti et al. 2003). Paraguay's Forest Law of 1973 also focuses on protection, requiring land owners to protect at least $25 \%$ of their property. However, failure to address the underlying land use and socioeconomic issues that are driving deforestation has resulted in Paraguay exhibiting one of the fastest deforestation rates in South America. The scenario analysis's capacity to highlight key drivers that, although obvious in hindsight, are not addressed by existing policy stems from its comprehensive scope. Full comprehension of the consequences of unsustainable agriculture in a finite landscape requires a longer view than that provided by subsistence farmers living day-to-day, decision makers focused on short-term economic growth, and conservationists beholden to crisis management. Applying scenario analysis to explore and communicate the potential consequences of multiple land uses operating over decades fosters the broader perspective needed for sustainably managing human activity within the Cuenca. The long-term focus of scenario analysis can help planners and stakeholders understand that the near-term economic cost of conservation actions (e.g., conservation agriculture) is frequently small relative to the long-term economic and environmental benefits. Simulation outcomes have helped to inform the development and implementation of a land use plan, and outcomes from a lessonslearned workshop indicated that the scenario analysis helped raise awareness of land use issues in the Cuenca among landowners, government agencies, and nongovernmental organizations.

Scenario analysis provides a framework for the integration of available information to assess the cumulative effects of land use over spatial and temporal scales relevant to land use planning. Knowledge gaps are inevitable, but the identification of uncertainties and their influence on simulation outcomes can help to focus and mobilize future research and improve land-use planning and management efforts. As long as the focus remains on identifying and communicating key drivers rather than making accurate predictions, similar analyses to inform land use planning should be feasible in other data-limited regions.

Responses to this article can be read online at: http://www.ecologyandsociety.org/voll6/iss3/art8/responses/ 


\section{Acknowledgments:}

The research was funded by the Canadian International Development Agency and the Alberta Research Council (now Alberta Innovates Technology Futures). The scenario analysis would not have been possible without the contributions of numerous individuals. Fudacion Moises Bertoni staff provided a wealth of knowledge as well great hospitality, in particular René Palacios, Yan Speranza, Evaristo Mendoza, and Luis Antúnez. We also thank farmers and park wardens from the Cuenca for the insight they provided. Several individuals from the Alberta Research Council contributed to the project, including Marian Weber, Laureen Elgert, Jennifer Karpyshyn, and Daiyuan Pan. Robin Naidoo provided land cover and conversion probability data and reviewed the manuscript. Rolf Derpsch provided information about conservation agriculture in the region. Brad Stelfox provided assistance with ALCES. We also thank two anonymous reviewers whose comments improved the article.

\section{LITERATURE CITED}

Alberta Environment. 2007. An examination of the effects of economic growth on landscape features and processes in southern Alberta using ALCES. Alberta Environment, Edmonton, AB, Canada.

Amado, T. J. C., C. Bayer, P. C. Conceicao, E. Spagnollo, B. Costa de Campos, and M. Da Veiga. 2006. Potential of carbon accumulation in no-till soils with intensive use and cover crops in southern Brazil. Journal of Environmental Quality 35:1599-1607. http://dx.doi.org/10.2134/jeq2005.0233

Brown, S. 1997. Estimating biomass and biomass change of tropical forests: a primer. FAO Forestry Paper 134, Food and Agriculture Organization of the United Nations, Rome.

Brown, S., A. J. R. Gillespie, A. E. Lugo. 1989. Biomass estimation methods for tropical forests with applications to forest inventory data. Forest Science 35:881-902.
Carlson, M., E. Bayne, and B. Stelfox. 2009. Assessing the future wildlife impacts of conservation and development in the Mackenzie watershed. Pages 531-540 in T. D. Rich, C. Arizmendi, D. Demarest and C. Thompson, editors. Proceedings of the Fourth International Partners in Flight Conference, 13-16 February 2008, McAllen, Texas, USA.

Carvalho, J. O. P., J. N. M. Silva, and J. C. A. Lopes. 2004. Growth rate of a terra firme rain forest in brazilian amazonia over an eight-year period in response to logging. ACTA Amazonica 34 (2):209-217. http://dx.doi.org/10.1590/S0044-5967 $\underline{2004000200009}$

Catterson, T. M., and F. V. Fragano. 2004. Tropical forestry and biodiversity conservation in Paraguay. Final Report of a Section 118/119 Assessment, EPIQ II Task No. 1, USAID, Asuncion, Paraguay.

Chiarello, A. G. 1999. Effects of fragmentation of the Atlantic forest on mammal communities in south-eastern Brazil. Biological Conservation 89 (1):71-82. http://dx.doi.org/10.1016/S0006-3207(98) $\underline{00130-X}$

Collen, B., M. Ram, T. Zamin, and L. McRae. 2008. The tropical biodiversity data gap: addressing disparity in global monitoring. Tropical Conservation Science 1(1). [online] URL: http://tropicalconserva tionscience.mongabay.com/content/v1/08-06-09Ben Collen et al.html

Di Bitetti, M. S., G. Placci, and L. A. Dietz. 2003. A biodiversity vision for the Upper Parana Atlantic Forest Ecoregion: designing a biodiversity conservation landscape and setting priorities for conservation action. World Wildlife Fund, Washington, D.C., USA.

Ditt, E. H., S. Mourato, J. Ghazoul, and J. Knight. 2010. Forest conversion and provision of ecosystem services in the brazilian atlantic forest. Land Degradation and Development 21:591-603. http://d $\underline{\text { x.doi.org/10.1002/ldr.1010 }}$

Dros, J. M. 2004. Managing the soy boom: two scenarios of soy production. AIDEnvironment, Amsterdam, The Netherlands.

[FAO] Food and Agriculture Organization. 2005. Livestock sector brief: Paraguay. Livestock 
Information, Sector Analysis and Policy Branch, FAO, Rome, Italy.

FAO. 2006. Global forest resources assessment 2005. FAO Forestry Paper 147, FAO, Rome, Italy.

Feldpausch, T. R., S. Jirka, C. A. M. Passos, F. Jasper, and S. J. Riha. 2005. When big trees fall: damage and carbon export by reduced impact logging in southern Amazonia. Forest Ecology and Management 219:199-215. http://dx.doi.org/10.1016/ j.foreco.2005.09.003

Florentin, M. A., M. Peoalva, A. Calegari, and R. Derpsch. 2001. Abonos verdes y rotacion de cultivos en siembra directa. Pequeoas propiedades. Proyecto Conservacion de Suelos MAG-GTZ, DEAG, San Lorenzo, Paraguay.

Fogel, R., and M. Riquelme. 2005. Enclave Sojero - merma de soberania y pobreza. Centro de Estudios Rurales Interdisciplinarios, Asuncion, Paraguay.

Galindo-Leal, C., and I. de Gusmao Câmara, editors. 2003. The Atlantic Forest of South America: biodiversity status, threats and outlook. Island Press, Washington, D.C., USA.

Gehring, C., M. Denich, and P. L. G. Vlek. 2005. Resilience of secondary forest regrowth after slashand-burn agriculture in central Amazonia. Journal of Tropical Ecology 21(5):519-527. http://dx.doi.or $\mathrm{g} / 10.1017 / \mathrm{S} 0266467405002543$

Geist, H. J., and E. F. Lambin. 2002. Proximate causes and underlying driving forces of tropical deforestation. Bioscience 52(2):143-150. http://dx.d oi.org/10.1641/0006-3568(2002)052[0143:PCAUDF] 2.0.CO;2

Glastra, R., editor. 1999. Cut and run: illegal logging and timber trade in the tropics. International Development Research Centre, Ottawa, ON, Canada.

Grauel, B. 1996. Regeneration offarmers' woodlots. Forest, Trees and People Newsletter 30, FAO, Rome, Italy.

Guerrero, A. C., and P. L. B. da Rocha. 2009. Passive restoration in biodiversity hotspots: consequences for an Atlantic rainforest lizard taxocene. Biotropica 42:379-387. http://dx.doi.org/ $\underline{10.1111 / \mathrm{j} .1744-7429.2009 .00584 . \mathrm{X}}$
Gullison, R. E., P. C. Frumhoff, J. G. Canadell, C. B. Field, D. C. Nepstad, K. Hayhoe, R. Avissar, L. M. Curran, P. Friedlingstein, C. D. Jones, and C. Nobre. 2007. Tropical forests and climate policy. Science 316:985-986. http://dx.doi.org/10.1126/sci ence. 1136163

Hill, K., G. McMillan, and R. Farina. 2003. Hunting-related changes in game encounter rates from 1994 to 2001 in the Mbaracayu Reserve, Paraguay. Conservation Biology 17:1312-1323. htt p://dx.doi.org/10.1046/j.1523-1739.2003.01135.x

Holmes, P. T., G. M. Blate, J. C. Zweede, R. Pereira Jr., P. Barreto, F. Boltz, and R. Bauch.1999. Financial costs and benefits of reduced impact logging relative to conventional logging in the Eastern Amazon. Tropical Forest Foundation, Washington, D.C., USA.

Huang, C., S. Kim, A. Altstatt, J. R. G. Townshend, P. Davis, K. Song, C. J. Tucker, O. Rodas, A. Yanosky, R. Clay, and J. Musinsky. 2007. Rapid loss of Paraguay's Atlantic forest and the status of protected areas: a Landsat assessment. Remote Sensing of Environment 106(4):460-466. http://dx.d oi.org/10.1016/j.rse.2006.09.016

Jackson, S. M., T. S. Fredericksen, and J. R. Malcolm. 2002. Area disturbed and residual stand damage following logging in a Bolivian tropical forest. Forest Ecology and Management 166:271-283. http://dx.doi.org/10.1016/S0378-1127(01)00681-8

Landers, J. N. 2007. Tropical crop-livestock systems in conservation agriculture, the Brazilian experience. Integrated Crop Management 5. Food and Agriculture Organization of the United Nations, Rome, Italy.

Lange, D. 2005. Economics and evolution of smallholdings conservation agriculture in Paraguay: mid-term experiences. FAO GTZ, Asuncion, Paraguay.

Lu, C. H., M. K. van Ittersum, and R. Rabbinge. 2003. A scenario exploration of strategic land use options for the Loess Plateau in northern China. Agricultural Systems 79:145-170. http://dx.doi.org/ 10.1016/S0308-521X(03)00069-6 
Metzger, J. P. 2002. Landscape dynamics and equilibrium in areas of slash-and-burn agriculture with short and long fallow period (Bragantina region, NE Brazilian Amazon). Landscape Ecology 17:419-431. http://dx.doi.org/10.1023/A:1021250306481

Ministerio de Agricultura y Ganaderia. 2004. Censo agropecuario nacional. Ministerio de Agricultura y Ganaderia, Asuncion, Paraguay.

Myers, N., R. A. Mittermeier, C. G. Mittermeier, G. A. B. da Fonseca, and J. Kent. 2000. Biodiversity hotspots for conservation priorities. Nature 403:853-858. http://dx.doi.org/10.1038/35002501

Naidoo, R., and W. L. Adamowicz. 2006. Modeling opportunity costs of conservation in transitional landscapes. Conservation Biology 20(2):490-500. http://dx.doi.org/10.1111/j.1523-1739.2006.00304. $\underline{x}$

Naidoo, R., and K. Hill. 2006. Emergence of indigenous vegetation classifications through integration of Traditional Ecological Knowledge and remote sensing and analyses. Environmental Management 38(3):377-387. http://dx.doi.org/10.1 $\underline{007 / \mathrm{s} 00267-004-0338-9}$

Naidoo, R., and T. H. Ricketts. 2006. Mapping the economic costs and benefits of conservation. PLoS Biology 4(11):e360. http://dx.doi.org/10.1371/journal. pbio.0040360

Pannell, D. J., G. R. Marshall, N. Barr, A. Curtis, F. Vanclay, and R. Wilkinson. 2006. Understanding and promoting adoption of conservation practices by rural landholders. Australian Journal of Experimental Agriculture 46(11):1407-1424. http:/ /dx.doi.org/10.1071/EA05037

Pence, G. Q. K., M. A. Botha, and J. K. Turpie. 2003. Evaluating combinations of on- and offreserve conservation strategies for the Agulhas Plain, South Africa: a financial perspective. Biological Conservation 112:253-273. http://dx.doi. org/10.1016/S0006-3207(02)00413-5

Peterson, G. D., G. S. Cumming, and S. R. Carpenter. 2003. Scenario planning: a tool for conservation in an uncertain world. Conservation
Biology 17(2):358-366. http://dx.doi.org/10.1046/j. 1523-1739.2003.01491.x

Pimm, S. L., and P. Raven. 2000. Extinction by numbers. Nature 403:843-845. http://dx.doi.org/10 $.1038 / 35002708$

Putz, F. E., K. H. Redford, J. G. Robinson, R. Fimbel, and G. M. Blate. 2000. Biodiversity conservation in the context of tropical forest management. The World Bank, Washington, D.C., USA.

Roper, J., and R. W. Roberts. 1999. Deforestation: tropical forests in decline. Forestry Issues Paper, Canadian International Development Agency, Ottawa, ON, Canada.

Schneider, R. R., J. B. Stelfox, S. Boutin, and S. Wasel. 2003. Managing the cumulative impacts of land uses in the Western Canadian Sedimentary Basin: a modeling approach. Conservation Ecology 7(1):8. [online] URL: http://www.consecol.org/vol7/ iss1/art8/

Schneider, R. R., J. B. Stelfox, S. Boutin, and S. Wasel. 2007. Scenarios are plausible stories about the future, not forecasts. Ecology and Society 12(1): r4. [online] URL: http://www.ecologyandsociety.org/ vol12/iss $1 /$ resp4/

Semino, S., L. Joensen, and J. Rulli. 2006. Paraguay sojero: soy expansion and its violent attack on local and indigenous communities in Paraguay. Grupo de Reflexion Rural, Argentina.

Sorrenson, W. J. 1997. Financial and economic implications of no-tillage and crop rotations compared to conventional cropping systems. TCI Occasional Paper Series No.9, FAO, Rome, Italy.

Sorrenson, W. J., C. Duarte, and J. López Portillo. 1998. Economics of no-till compared to conventional cultivation systems on small farms in Paraguay: policy and investment implications. Final Report to the MAG/GTZ Soil Conservation Project, FAO.

Tabarelli, M., A. V. Aguiar, M. C. Ribeiro, J. P. Metzger, and C. A. Peres. 2010. Prospects for biodiversity conservation in the Atlantic Forest: lessons from aging human-modified landscapes. 
Biological Conservation 143(10):2328-2340. http:/ /dx.doi.org/10.1016/j.biocon.2010.02.005

United Nations. 2009. Millenium development goals indicators: the official United Nations site for the MDG indicators. [online] URL: http://unstats.un. org/unsd/mdg/default.aspx

[UNDP] United Nations Development Program. 2003. Atlas de desarrollo humano, Paraguay 2003.

UNDP, Paraguay.

Vanclay, J. K. 1994. Modelling forest growth and yield: applications to mixed tropical forests. Centre for Agriculture and Biosciences International, Wallingford, UK.

Van Ittersum, M. K., R. Rabbinge, and H. C. van Latesteijn. 1998. Explorative land use studies and their role in strategic policy making. Agricultural Systems 58:309-330. http://dx.doi.org/10.1016/S03 08-521X(98)00033-X

Zarin, D. J., M. J. Ducey, J. M. Tucker, and W. A. Salas. 2001. Potential biomass accumulation in Amazonian regrowth forests. Ecosystems 4:658-668. http://dx.doi.org/10.1007/s10021-001-0035-y

Zwick, S. 2008. Mbaracayu: lessons in avoiding deforestation. Ecosystem Marketplace Community Forum 3(1). [online] URL: http://www.ecosystemm arketplace.com/pages/dynamic/newsletter.page.php? page $\mathrm{id}=7290 \& ;$ section=newsletters \&; $\mathrm{eod}=1$ 